\title{
Soil Fumigation, Fruit Production, and Dry Matter Partitioning of Field-grown Strawberry Plants
}

\author{
Kirk D. Larson ${ }^{1}$ and Douglas V. Shaw ${ }^{2}$ \\ Department of Pomology, University of California, Davis, CA 95616
}

Additional index words. chloropicrin, Fragaria $\times$ ananassa, methyl bromide, nonfumigation, photoassimilate, shoot : root ratio, trichloronitromethane, vegetative growth

\begin{abstract}
Bare-rooted 'Camarosa' strawberry runner plants were established in a fruit production field on 1 Nov. 1993 using annual hill culture and two preplant soil fumigation treatments: 1) a mixture of 2 methyl bromide : 1 chloropicrin

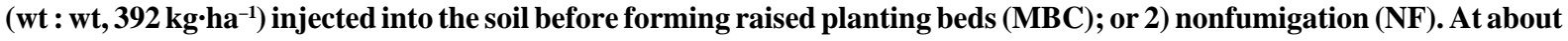
33-day intervals between mid-January and the end of May, 20 plants were destructively sampled from each treatment to determine leaf dry mass (LDM), crown dry mass (CDM), root dry mass (RDM), and shoot : root dry mass (SRDM) ratios. Plant mortality was $<0.2 \%$ throughout the study and did not differ with soil treatment. Regardless of sampling date, LDM, CDM, and RDM were greater for MBC plants than for NF plants, although treatment differences were not always significant. During the first 143 days, NF plants allocated a greater proportion of dry matter to roots than to shoots compared to MBC plants, indicating that roots are a stronger sink for photoassimilate in nonfumigated than in fumigated soils. However, there was no difference between treatments in SRDM by the end of the study. Fruit yield and a 10-fruit weight were determined at weekly intervals from mid-January until 23 May 1994. Yield and mean fruit weight of NF plants were $72 \%$ and $90 \%$, respectively, of that of $\mathrm{MBC}$ plants. For both treatments, about one-half of total fruit production occurred between 144 and 174 days after planting (late March to late April). During that same period, rates of dry matter accumulation in leaf, crown, and root tissues decreased for plants in both treatments, but greatest reductions occurred in NF plants. Chemical name used: trichloronitromethane (chloropicrin).
\end{abstract}

California strawberry production has an annual farm gate value of more than $\$ 600,000,000$ and accounts for about $80 \%$ and $85 \%$ of the U.S. fresh market and processing strawberry crop, respectively (Bertelsen, 1995). In California and other highly productive strawberry growing areas, preplant soil fumigation with methyl bromide (MB), or with mixtures of $\mathrm{MB}$ and chloropicrin (MBC), is a standard practice for controlling soilborne plant pathogens, nematodes, and weeds (Voth and Bringhurst, 1990; Wilhelm and Paulus, 1980). Controlling specific lethal soilborne pathogens and yield and certain plant growth responses to soil fumigation are well documented for strawberry (Himelrick and Dozier, 1991; Larson and Shaw, 1995a, 1995b; Wilhelm and Paulus, 1980; Wilhelm et al., 1974; Yuen et al., 1991); however, relatively few studies have examined the influence of preplant soil fumigation on fruit yield and dry matter partitioning throughout an extended (i.e., 5 months or longer) strawberry fruiting season, such as occurs in California. The recent classification of $\mathrm{MB}$ as an ozone-depleting compound (Watson et al., 1992) and the U.S. Environmental Protection Agency's decision to eliminate production and use of this compound necessitate an improved understanding of the effects of preplant soil treatments on strawberry plant growth and development.

Determining seasonal patterns of fruiting and vegetative growth could help identify critical periods during which nutrient, water, or photoassimilate availability may limit plant growth and productivity. Such information could assist in developing production systems that optimize resource allocation, particularly in the absence of MB soil fumigation. Our objective in conducting this study was to determine the influence of soil fumigation treatment on fruit

Received for publication 29 Feb. 1996. Accepted for publication 8 July 1996 . We gratefully acknowledge the cooperation of Tri-Cal, Hollister, Calif., and SierraCascade Nursery, Susanville, Calif., in conducting this study. The cost of publishing this paper was defrayed in part by the payment of page charges. Under postal regulations, this paper therefore must be hereby marked advertisement solely to indicate this fact.

${ }^{1}$ Assistant pomologist, Univ. of California South Coast Research and Extension Center, 7601 Irvine Blvd., Irvine, CA 92718.

${ }^{2}$ Associate professor. yield and dry matter partitioning among strawberry plant vegetative tissues during a 5-month fruiting season.

\section{Materials and Methods}

The trial was conducted at the Univ. of California South Coast Research and Extension Center, Irvine, on soil that had been cropped in strawberry in alternate years for the past 30 years. Each of the 15 previous strawberry production cycles was preceded by a cover crop of barley (Hordeum vulgare L.), and strawberries were grown with preplant soil fumigation using a (wt : wt) mixture of 2 methyl bromide : 1 chloropicrin (MBC) at a rate of $392 \mathrm{~kg} \cdot \mathrm{ha}^{-1}$. To compare experimental soil fumigation treatments, adjacent parcels were either treated with a the mixture of $\mathrm{MBC}$ injected into the soil at a rate of $392 \mathrm{~kg} \cdot \mathrm{ha}^{-1}$ before forming raised planting beds or left nonfumigated (NF), with two replicates for each soil treatment.

Bare-rooted 'Camarosa' runner plants, consisting of crowns and roots, were harvested from a commercial propagation nursery near Susanville, Calif., on 23 Oct., stored at $1{ }^{\circ} \mathrm{C}$, and planted in experimental plots on 1 Nov. 1993. Before planting, 20 runner plants were sampled at random, washed thoroughly, divided into root and crown tissues, and dried at $65^{\circ} \mathrm{C}$ for $4 \mathrm{~d}$ to determine initial mean root dry mass (RDM) and crown dry mass (CDM). Plants were established in offset double rows on beds $122 \mathrm{~cm}$ wide $\times 40$ $\mathrm{cm}$ high using a 41-cm in-row plant spacing (40,363 plants/ha), with six 20-plant plots in each treatment-replicate combination. For each replicate, three plots were destructively subsampled at periodic intervals to determine vegetative tissue dry matter, while the remaining three plots in each replicate were used to determine fruit yield.

All plots were maintained according to recommendations for California commercial winter plantings (Welch, 1989). Nonfumigated plots had substantially greater weed populations than fumigated plots, and all weeds were removed by hand at monthly intervals from all plots to reduce any treatment differences due to weed competition. 
On 18 Jan., $78 \mathrm{~d}$ after planting and just before the first fruit harvest, one half-plot consisting of 10 plants ( 5 adjacent plants from each side of the bed) was chosen at random from the three plots per replicate designated for destructive sampling (20 plants per treatment). Individual plants were carefully dug by hand and washed in the field to remove most of the soil from the roots, then placed in plastic bags and kept at $2{ }^{\circ} \mathrm{C}$ until all plants to be sampled on that date were harvested. In the laboratory, harvested plants were carefully washed and divided into root, crown and leaf tissues, and dried at $70{ }^{\circ} \mathrm{C}$ for $4 \mathrm{~d}$ for subsequent determination of leaf (laminae + petiole) dry mass (LDM), CDM, RDM, and shoot : root dry mass (SRDM) ratios (shoot dry mass $=\mathrm{CDM}+\mathrm{LDM})$. Originally, plants were destructively harvested to quantify dry weight of dead and live leaves separately, but, over the course of the experiment, abscission and decay of older leaves in the field made accurate recovery of dead leaves difficult. Therefore, LDM was determined using living tissue only.

Using the sampling procedures described above, additional 10plant subplots were destructively harvested from each replicate at 110, 143, 174, and 207 d after planting (19 Feb., 24 Mar., 24 Apr., and 27 May, respectively), for a total of six destructive samplings. Preliminary analyses indicated no replicate or replicate $\times$ treatment interactions for LDM, CDM, or RDM for any sampling date (data not shown). Therefore, for each sampling date, treatment differences in tissue dry mass were analyzed using combined error terms and a Student's $t$ test.

Fruit harvest commenced 19 Jan., 79 d after planting. Fruit were harvested weekly from all plots using commercial fruit maturity standards; yield and a 10-fruit weight were determined for three plots in each replicate. Fruit harvesting was terminated on 23 May. For both treatments, fruit yield and a 10-fruit weight were determined for each plot on a per-plant basis. Fruit yields also were determined for each plot on a per-plant basis for each of the destructive plant sampling intervals in which fruit were harvested, i.e., 79 to $110 \mathrm{~d}$ after planting (18 Jan. to $19 \mathrm{Feb}$.), 111 to $143 \mathrm{~d}$ after planting (20 Feb. to 24 Mar.), 144 to $175 \mathrm{~d}$ after planting (25 Mar. to 24 Apr.), and 176 to $207 \mathrm{~d}$ after planting (25 Apr. to 27 May). Preliminary analyses indicated no replicate or replicate $\times$ treatment interactions for total yield, fruit weight, or sampling interval yield (data not shown). Therefore, differences between treatments in total yield, fruit weight and sampling interval yield were analyzed using combined error terms and a Student's $t$ test.

\section{Results and Discussion}

Initial runner plant RDM and CDM (mean \pm standard errors) were $1.23 \mathrm{~g}( \pm 0.15 \mathrm{~g})$ and $0.82 \mathrm{~g}( \pm 0.08 \mathrm{~g})$. In the field, $<0.2 \%$ of plants died, with no differences detected between treatments for plant mortality (data not shown), and no visual symptoms of crown or root diseases.

A significant $(P<0.05)$ fumigation growth response was first detected on day 78, at which time there was a 1.36-fold increase in LDM for plants in fumigated compared to nonfumigated soils (Table 1). For all five destructive harvests, MBC plants had greater RDM, CDM, and LDM compared to NF plants, although differences between treatments were not always significant (Table 1). For NF plants, LDM ranged from $66 \%$ to $82 \%$ (average $74 \%$ ), CDM from $66 \%$ to $85 \%$ (average $74 \%$ ), and RDM from $70 \%$ to $95 \%$ (average $84 \%$ ) of that of LDM, CDM, and RDM for MBC plants, respectively. At $110 \mathrm{~d}$ after planting, soil fumigation resulted in a 1.4-, 1.5-, and 1.2-fold increase in LDM, CDM, and RDM, respectively, compared to nonfumigation (Table 1). Thus, although soil fumigation resulted in increased dry mass for all tissues, RDM was less affected than LDM or CDM, and consequently MBC plants had a larger SRDM than NF plants at days 110 and 143 (Table 1). The smaller SRDM (i.e., the larger root : shoot

Table 1. Root, crown, leaf dry weights, and shoot : root dry mass ratios ${ }^{\mathrm{z}}$ for six destructive sampling dates and fruit yieldy for four fruit harvest intervals for annual hill-cultured 'Camarosa' strawberry plants grown with (+) or without (-) preplant soil fumigation.

\begin{tabular}{|c|c|c|c|c|c|c|c|}
\hline $\begin{array}{l}\text { Sampling } \\
\text { date (day } \\
\text { after planting) }\end{array}$ & $\begin{array}{c}\text { Soil } \\
\text { treatment }^{\mathrm{w}}\end{array}$ & $\begin{array}{c}\text { Leaf } \\
\text { dry mass (g) }\end{array}$ & $\begin{array}{c}\text { Crown } \\
\text { dry mass (g) }\end{array}$ & $\begin{array}{c}\text { Root } \\
\text { dry mass (g) }\end{array}$ & $\begin{array}{l}\text { Shoot : root } \\
\text { dry mass }^{v}(g)\end{array}$ & $\begin{array}{c}\text { Fruit } \\
\text { harvest interval } \\
\text { (days after planting) }\end{array}$ & $\begin{array}{c}\text { Fruit } \\
\text { yield }^{\mathrm{y}} \\
\text { (g/plant) }\end{array}$ \\
\hline$\overline{0}$ & & --- & $0.82(0.08)$ & $1.23(0.15)$ & $0.67(0.05)$ & & \\
\hline \multirow[t]{2}{*}{78} & $(+)$ & $7.08(0.67)$ & $1.98(0.19)$ & $2.14(0.16)$ & $4.22(0.26)$ & $1-78$ & --- \\
\hline & $(-)$ & $\begin{array}{c}5.22(0.54) \\
t=2.16^{* u}\end{array}$ & $\begin{array}{c}1.61(0.17) \\
t=1.45\end{array}$ & $\begin{array}{c}2.04(0.24) \\
t=0.35\end{array}$ & $\begin{array}{c}3.57(0.26) \\
t=1.77\end{array}$ & & --- \\
\hline \multirow[t]{2}{*}{110} & $(+)$ & $20.09(1.14)$ & $6.08(0.40)$ & $3.30(0.22)$ & $8.14(0.32)$ & $79-110$ & $93.56(5.20)$ \\
\hline & $(-)$ & $\begin{array}{c}14.20(1.32) \\
t=3.37^{* * *}\end{array}$ & $\begin{array}{c}4.08(0.34) \\
t=3.83^{* *}\end{array}$ & $\begin{array}{c}2.71(0.19) \\
t=2.07^{*}\end{array}$ & $\begin{array}{c}6.70(0.41) \\
t=2.76^{* * *}\end{array}$ & & $\begin{array}{c}63.02(4.90) \\
\mathrm{t}=4.28 * *\end{array}$ \\
\hline \multirow[t]{2}{*}{143} & $(+)$ & $39.35(3.53)$ & $11.55(0.87)$ & $3.31(0.29)$ & $16.03(1.00)$ & $111-143$ & 248.33 \\
\hline & $(-)$ & $\begin{array}{c}32.20(2.79) \\
t=1.59\end{array}$ & $\begin{array}{c}8.04(0.45) \\
t=3.59^{* *}\end{array}$ & $\begin{array}{c}3.15(0.27) \\
t=0.40\end{array}$ & $\begin{array}{c}13.32(0.71) \\
t=2.20^{*}\end{array}$ & & $\begin{array}{c}154.68(9.80) \\
t=4.08^{* *}\end{array}$ \\
\hline \multirow[t]{2}{*}{175} & $(+)$ & $48.45(3.30)$ & $12.76(0.72)$ & $3.08(0.22)$ & $20.46(0.90)$ & $144-175$ & $803.98(12.79)$ \\
\hline & $(-)$ & $\begin{array}{c}31.95(2.72) \\
t=3.82^{* *}\end{array}$ & $\begin{array}{c}8.45(0.66) \\
t=4.38^{* *}\end{array}$ & $\begin{array}{l}2.16(0.13) \\
t=3.64^{* *}\end{array}$ & $\begin{array}{c}18.69(1.07) \\
t=1.24\end{array}$ & & $\begin{array}{c}644.93(10.46) \\
t=9.63^{* *}\end{array}$ \\
\hline \multirow[t]{2}{*}{207} & $(+)$ & $65.95(4.02)$ & $19.09(0.90)$ & $4.02(0.24)$ & $21.74(1.20)$ & $176-207$ & $558.33(25.2)$ \\
\hline & $(-)$ & $\begin{array}{c}51.06(4.07) \\
t=2.60^{*}\end{array}$ & $\begin{array}{c}18.27(1.86) \\
t=0.38\end{array}$ & $\begin{array}{c}3.14(0.26) \\
t=2.48^{*}\end{array}$ & $\begin{array}{c}22.32(1.42) \\
t=0.32\end{array}$ & & $\begin{array}{c}364.03(9.08) \\
t=7.25^{* * *}\end{array}$ \\
\hline
\end{tabular}

${ }^{\mathrm{z} L e a f}$, crown, root, and shoot : root dry mass values represent means of 20 plants, with sE reported in parentheses.

yFruit yield values represent mean per-plant yield for six 20-plant plots, with SE reported in parentheses.

xPlanted 1 Nov. 1993.

${ }^{\mathrm{w}}(+)$ Mixture of 67 methyl bromide : 33 chloropicrin at $392 \mathrm{~kg} \cdot \mathrm{ha}^{-1} ;(-)$ nonfumigated.

"Shoot dry mass $=$ crown dry mass + leaf dry mass.

"Mean separation within columns for each sampling date or harvest interval using a Student's $t$ test.

${ }^{*, * *}$ Significant at $P=0.05$ or 0.01 , respectively. 
dry mass ratio) for NF plants compared to MBC plants during the first $143 \mathrm{~d}$ indicates a shift in dry matter allocation from shoot to root, suggesting that strawberry roots are a relatively stronger sink for photoassimilate in nonfumigated than fumigated soils.

Dry matter accumulation in strawberry roots reportedly reaches a relatively stable level within several months of planting, after which shoot growth or fruit development minimizes root dry
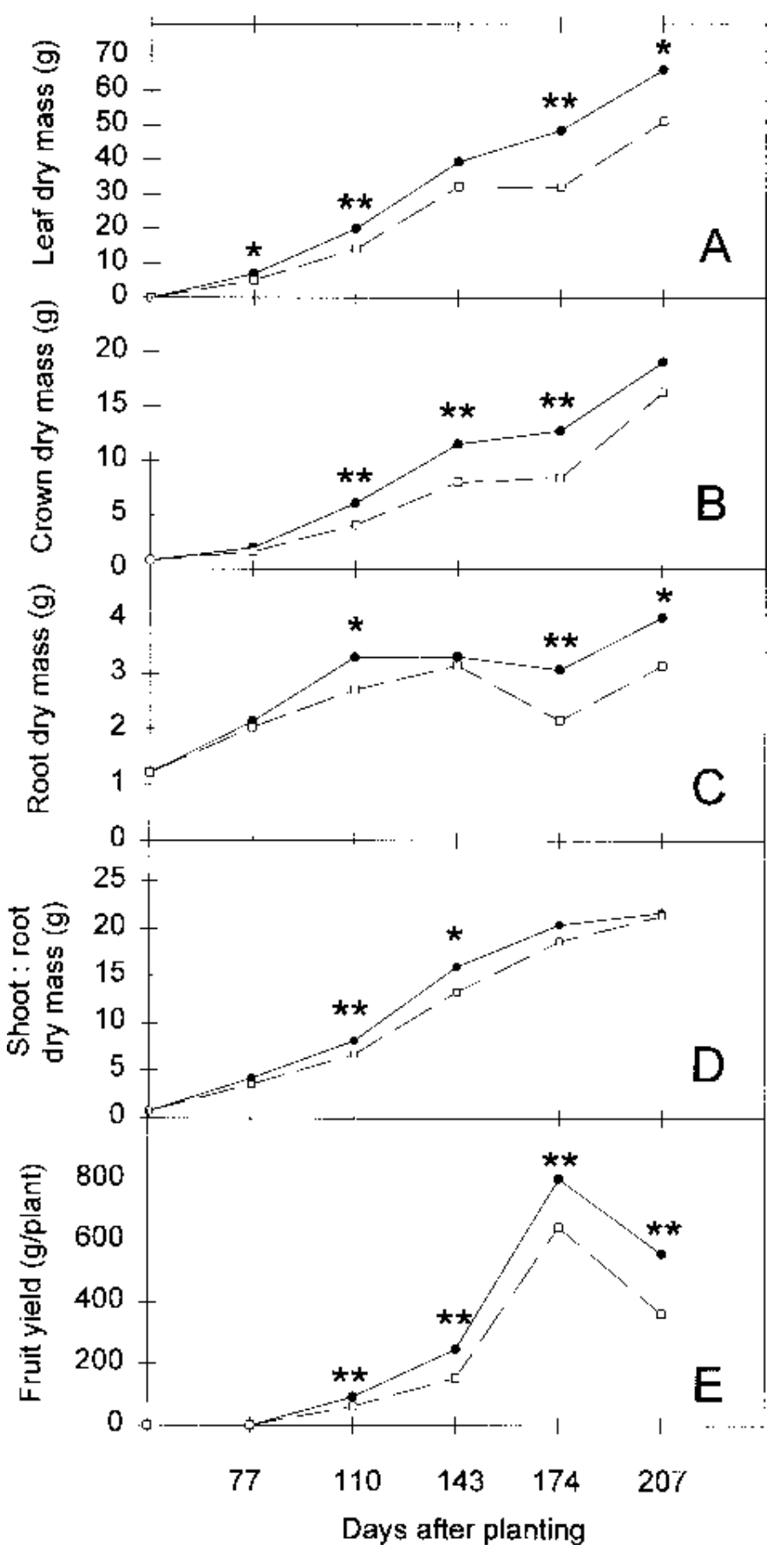

Fig. 1. Influence of nonfumigation ( $\square$ ) and preplant soil fumigation with $392 \mathrm{~kg}$ ha1 of a (wt : wt) of 2 methyl bromide : 1 chloropicrin (O) on seasonal dry matter partitioning and fruit yield of 'Camarosa' strawberry plants; (A) leaf dry mass; (B) crown dry mass; (C) root dry mass; (D) shoot : root dry mass ratio; and (E) fruit yield; for vegetative tissue dry masses, symbols represent means of 20 plants; for fruit yields, symbols represent mean per-plant yield for six 20-plant plots. ${ }^{*}$ "** Significant treatment differences $(P=0.05$ and 0.01 , respectively $)$ in dry mass or fruit yield using a Student's $t$ test. matter accumulation (Forney and Breen, 1985; Galletta and Bringhurst, 1991; Olsen et al., 1985). Similarly, we observed only slight increases in RDM after day 110 for plants in either treatment, but LDM and CDM continued to increase several-fold during the remainder of the study (Table 1, Fig. 1). However, a large portion of the strawberry root system is comprised of relatively short-lived feeder rootlets that have a lifespan of only a few days or weeks, and feeder roots are constantly regenerated, often in the same sites as the original rootlet (Wilhelm and Nelson, 1970). The relatively high rate of senescence and renewal of the strawberry feeder rootlet system may account for the homeostasis in RDM observed in this and other studies, but also suggests that substantial amounts of root biomass may be unaccounted for due to root turnover. For strawberry plants grown in nonfumigated compared to fumigated soil, higher root turnover rates, possibly as a result of sublethal soilborne pathogens (Wilhelm et al., 1974; Yuen et al., 1991), could represent a large sink for photoassimilate and result in fewer resources available for vegetative growth and fruit production.

No difference in SRDM was observed between treatments after day 143. Thus, despite the differences between treatments in plant size and initial differences in root and shoot dry matter allocation patterns, plants eventually attained a similar SRDM, regardless of soil treatment and plant vigor.

Highly significant increases in yield for all four harvest intervals, as well as highly significant increases in total yield and fruit size, were detected due to preplant soil fumigation (Tables 1 and 2 ). Thus, the larger plants, and in particular, the greater crown and leaf mass for the MBC plants, resulted in increased reproductive capacity compared to plants in nonfumigated soil. For NF plants, mean fruit weight, early season yield (to $143 \mathrm{~d}$ after planting, i.e., to 24 Mar.), late season yield (from days 144 to 203 after planting, i.e., from 25 Mar. to 23 May), and total fruit production were about $90 \%, 64 \%, 74 \%$, and $72 \%$, respectively, of that of the MBC treatment plants.

Fruit production between days 144 and 175 (i.e., from 25 Mar. to 24 Apr.) accounted for $44 \%$ and $53 \%$ of the total yields for the MBC and NF treatments, respectively (Table 1), and we observed a concomitant decrease in the rate of dry matter accumulation in leaves, crowns, and roots for both treatments as well (Fig. 1 A-D). Apparently, fruit development during this period monopolized available photoassimilate and nutrients, resulting in reduced vegetative growth for both treatments during this interval. During this period, RDM decreased $7 \%$ and $31 \%$ for $\mathrm{MBC}$ and NF plants (Table 1), respectively, and total vegetative biomass of NF plants also decreased at this time (Table 1, Fig. 1 A-C). Thus, vegetative

Table 2. Total yield and mean fruit wt for annual hill-cultured 'Camarosa' strawberry plants grown with (+) or without (-) preplant soil fumigation.

\begin{tabular}{lcc}
\hline $\begin{array}{l}\text { Soil } \\
\text { treatment }\end{array}$ & $\begin{array}{c}\text { Total yield } \\
\text { ( }\end{array}$ & $\begin{array}{c}\text { Fruit } \\
\mathrm{wt}^{\mathrm{x}}(\mathrm{g})\end{array}$ \\
\hline$(+)$ & $1704.20(18.01)$ & $30.25(0.37)$ \\
$(-)$ & $1227.35(15.05)$ & $27.24(0.40)$ \\
& $\mathrm{t}=16.87^{* * * \mathrm{w}}$ & $\mathrm{t}=5.54^{* *}$
\end{tabular}

${ }^{\mathrm{z} Y i e l d}$ for period 18 Jan. to 23 May 1994; yield values represent mean perplant yield for six 20-plant plots, with SE reported in parentheses.

$\mathrm{y}(+)$ Mixture of 2 methyl bromide : 1 chloropicrin at $392 \mathrm{~kg} \cdot \mathrm{ha}^{-1} ;(-)$ nonfumigated.

${ }^{\mathrm{x}}$ Seasonal fruit wt calculated from weekly 10 -fruit samples for each of 6 20-plant plots, with SE reported in parentheses.

"Mean separation within columns using a Student's $t$ test.

** Significant at $P=0.01$ 
growth inhibition due to fruiting was greatest for NF plants, especially for root growth, suggesting that the capacity to sustain allocation of resources to the supportive and assimilative structures of the plant is a key feature of the fumigation response.

Inhibitory effects of fruiting on strawberry plant vegetative growth and associated changes in dry matter partitioning have been observed in many other studies (Forney and Breen, 1985; Hancock and Cameron, 1987; Jahn and Dana, 1966; Schaffer et al., 1986; Olsen et al., 1985), indicating that developing strawberry fruit are strong sinks for dry matter. Jahn and Dana (1966) and Waldo (1935) observed that the inhibition of strawberry vegetative growth due to fruiting decreased with increasingly favorable growth conditions, such as adequate soil moisture. In our study, an improved production environment due to soil fumigation resulted in increased vegetative growth and fruit production and a smaller reduction in vegetative growth during the peak fruiting period, despite a heavier fruit load, for MBC plants compared to NF plants. However, the mechanism by which fumigation favorably enhances strawberry growth and yield is unclear, as no plant mortality or lethal pathogens were observed. The fumigation response may be the result of several factors, including an absence of competition for resources, and a larger, healthier root system that is better able to exploit the rhizosphere. If so, strawberry crop management programs that result in increased plant vigor, enhanced nutrient availability, or improved soil moisture status may be useful for optimizing the production environment in the absence of effective soil fumigation.

\section{Literature Cited}

Bertelsen, D. 1995. The U.S. strawberry industry. U.S. Dept. Agr. Stat. Bul. 914.

Forney, C.F. and P.J. Breen. 1985. Dry matter partitioning and assimilation in fruiting and deblossomed strawberry. J. Amer. Soc. Hort. Sci. 110:181-185.

Jahn, O.L. and M.N. Dana. 1966. Fruiting and growth of the strawberry plant. Proc. Amer. Soc. Hort. Sci. 88:352-359.

Galletta, G.J., and R.S. Bringhurst. 1990. Strawberry management, p. 83
157. In: G.J. Galletta and D.G. Himelrick (eds.). Small fruit crop management. Prentice-Hall, Englewood Cliffs, N.J.

Hancock, J.F. and J.S. Cameron. 1987. Effect of harvesting in the first year on subsequent yield and dry matter partitioning in strawberry. Adv. Strawberry Prod. 6:7-10.

Himelrick, D.G. and W.A. Dozier, Jr. 1991. Soil fumigation and soil solarization in strawberry production. Adv. Strawberry Prod. 10:12-28.

Larson, K.D. and D.V. Shaw. 1995a. Relative performance of strawberry genotypes on fumigated and nonfumigated soils. J. Amer. Soc. Hort. Sci. 120:274-277.

Larson, K.D. and D.V. Shaw. 1995b. Strawberry nursery soil fumigation and runner plant production. HortScience 30:236-237.

Olsen, J., L.W. Martin, P.J. Pelofske, P.J. Breen, and C.F. Forney. 1985. Functional growth analysis of the strawberry. J. Amer. Soc. Hort. Sci. 110:89-93.

Schaffer, B., J.A. Barden, and J.M. Williams. 1986. Whole plant photosynthesis and dry-matter partitioning in fruiting and deblossomed dayneutral strawberry plants. J. Amer. Soc. Hort. Sci. 111:430-433.

Voth, V. and R.S. Bringhurst. 1990. Culture and physiological manipulation of California strawberries. HortScience 25:889-892.

Watson, R.T., D.L. Albritton, S.O. Anderson, and S.E. Bapty. 1992 Methyl bromide: Its atmospheric science, technology, and economics. Montreal Protocol Assessment Summary, United Nations Environment Program, Nairobi, Kenya.

Waldo, G.F. 1935. Investigations on runner and fruit production of everbearing strawberries. U.S. Dept. of Agr. Tech. Bul. 470.

Welch, N. 1989. Strawberry production in California. Univ. of California Coop. Ext. Lflt. 2959.

Wilhelm, S. and P.E. Nelson. 1970. A concept of rootlet health of strawberries in pathogen-free soil achieved by fumigation. In: T.A. Toussoun, R.V. Bega, and P.E. Nelson (eds.). Root diseases and soilborne pathogens. Univ. of Calif. Press, Berkeley.

Wilhelm, S., R.C. Storkan, and J.M. Wilhelm. 1974. Preplant soil fumigation with methyl bromide-chloropicrin mixtures for control of soilborne diseases of strawberries-A summary of fifteen years of development. Agr. Environ. 1:227-236.

Wilhelm, S. and A.O. Paulus. 1980. How soil fumigation benefits the California strawberry industry. Plant. Dis. 64:264-270.

Yuen, G.Y., M.N. Schroth, A.R. Weinhold, and J.G. Hancock. 1991. Effects of soil fumigation with methyl bromide and chloropicrin on root health and yield in strawberry. Plant Dis. 75:416-420. 